\title{
Electronic payment adoption and consumers' spending growth: empirical evidence from Nigeria
}

\author{
Lukman O. Oyelami ${ }^{1 *}$, Sulaimon O. Adebiyi ${ }^{2}$ and Babatunde S. Adekunle ${ }^{1}$
}

\begin{abstract}
The study investigates the determinants of electronic payment adoption and the role of electronic payment on consumers' purchase decisions as well as its effects on consumers' spending growth in Nigeria. To achieve this, both primary and secondary data were deployed. The primary data were collected through a cross-sectional survey of banks' customers who have experienced the e-payment modes in Lagos state, Nigeria. The questionnaire was designed in line with Likert scale and validated. Fifty copies of the questionnaire were piloted. The copies retrieved were subjected to Cronbach alpha test of reliability. All the six variables were found to be reliable ranging between 0.725 and 0.828 Cronbach alpha values, which are within the acceptable limit. The sample size for this study, as determined through Cochran formulae is 384. In like manner, the instrument of data collection was administered on 420 respondents by using the multistage sampling technique to sample respondents across five divisions (locations) of Lagos. The data retrieved were analysed using descriptive (frequency and percentage) and inferential statistics (Pearson correlation, hierarchical regression analysis and analysis of variance). The results revealed that there is a positive significant relationship between electronic payment systems determinants (convenience, security and safety, trust, social influence) and e-payment adoption in Nigeria. These variables accounted for more than half $(3 / 5)$ of what influences consumers' adoption of e-payment mode of transaction in Nigeria. The results from the estimations show that factors such as educational attainment, financial inclusion, income level, internet service availability and other financial infrastructures such as point-of-sale machines and mobile banking services are critical determinants of e-payment adoption in Nigeria. The results also indicate that electronic payment influences consumers' purchase decisions and thus increasing consumers' spending growth in Nigeria. The policy implication advanced by this study is that the Nigerian government can leverage on electronic payment to increase consumers'spending and thus improve aggregate demand which will consequently stimulate investment and economic growth in the country.
\end{abstract}

Keywords: E-payment, Adoption, Growth, ARDL, Survey, Consumer spending, Nigeria

JEL Classification: G23, G2, E0, C5

\section{Introduction}

Most commercial transactions in Nigeria rely heavily on cash [9]. It has been estimated, in fact, that more than $95 \%$ of commercial transactions in the country are cash dependent. The implication of this practice is that

\footnotetext{
*Correspondence: loyelami@unilag.edu.ng

1 Economics Unit, Distance Learning Institute, University of Lagos, Lagos, Nigeria

Full list of author information is available at the end of the article
}

the Central Bank of Nigeria-saddled with responsibility of printing and minting Nigeria's currency-must up its fiduciary responsibility by printing regularly, so as to facilitate economic transactions and boost economic growth in the country. Cash transactions represented over $99 \%$ of customer activity in banks, and $10 \%$ of number of cash transactions are above 150, 000 (CBN) 2010. This is a huge responsibility, given the volume of transactions that take place in the Nigerian economy. By CBN 
projection, all things being equal, direct cost of cash was estimated to reach $192 \mathrm{~b}$ in 2012 , and this basically include, cash in transit cost (27.3b), cash processing cost (69.1b) and vault management cost (18.1b). Apart from the direct cost of cash economy to the banking sector, other challenges of cash-based economy include security risk and lack of transparency.

More importantly, heavy cash usage allocates huge money outside the formal economy. This contributes to limiting the effectiveness of monetary policy in managing inflation and stimulating growth [9]. To overcome these challenges, monetary authorities realized the need to reinvent a more efficient payment system for the Nigerian economy, and this led to the introduction of cashless payment policy in 2012. In addition, the wave of innovative ICT adoption in the banking system across the country in the last decade gave birth to introduction of debit and credit card which provides opportunity for low income depositors to use automated teller machine (ATM). This also prepared a fertile ground for the adoption of electronic payment system [5, 14, 33]. Cashless payment has always been a part of the payment system in the country. However, it has all along be limited to Nigerian cities who gave access to the use of cheque and fund transfer.

Given the deficient financial infrastructure and other socio-economic conditions in the country, cashless policy which basically depends on electronic payment cannot just be free of challenges. In 2012, when the policy was introduced, according to Findex data, there was 491.2 numbers of transactions account per 1000 adults; 11.4 number of ATMs per 100,000 adults; only $16.1 \%$ of the population have access to the internet service and 294 secured internet servers were available. This is grossly inadequate, given the population of $177,475,986$ with estimated growth rate of $2.5 \%$ and Gross National Product (GDP) of $\$ 461$ billion. During the same period, the per capita income was $\$ 2296.5$, the percentage of Nigerian in extreme poverty was $38.7 \%$, and household final consumption expenditure per capita was \$1414.1. Despite all these challenges, the implementation of cashless policy commenced in March 2012.

The policy implementation provides consumers in Nigeria with more options to execute their transactions. This may have influenced the consumption spending of many Nigerian households. Studies have shown that the payment mechanism can influence consumers' spending $[10,15,19,21,30,34]$. However, many studies conducted in Nigeria have not really given attention this. Generally, in the course of time, efforts have been made to assess the impact of cashless policy vis-à-vis electronic payment on several economic variables in Nigeria $[4,7,36$, 37]. Outside Nigeria as well, studies have established a link between electronic payment and economic growth, financial inclusion and household consumption [24, 25, $29,35]$.

However, studies have hardly examined closely the determinants of electronic payment adoption and the role of electronic payment adoption on consumers' purchase decisions as well as its effects on household spending growth in Nigeria. This may partly be due to the non-availability of long time data for such empirical exercise. Basically, the focus of this study is to investigate determinants of electronic payment adoption, its influence on consumers' purchase decisions and household spending growth. Apart from the introduction, this paper comprises four separate but related sections. The first section already prepared ground for the discussion in this study. Second part will concentrate on stylized facts of electronic payment and financial inclusion in Nigeria. The third section is purely complementary, as it will review literatures that are relevant to the variables under study. While the focus of section four is on identifying the methods deployed in this study and the results obtained, section five concludes this paper and makes some vital policy implication.

\section{Stylized facts of electronic payment and financial inclusion in Nigeria}

Figure 1 shows the performance of different electronic payment platforms in Nigeria in terms of number of transaction on each platform on a monthly basis. The period of observation spans between January 2012 and June 2017. The selection of 2012 is as a result of introduction of cashless policy during the period. The casual look at the figure shows upward trend in the number of transaction across the platform. For instance, ATM transaction has almost tripled within the space of 4 years. The reason for the proliferation is that it is the most assessed electronic payment platform. Specifically, the number of ATM transactions increased from 22 million in 2012 to about 65 million in February 2017. Other payment platforms have not shown this huge increase, but they have shown some level of improvement, especially the instant payment (NIP) and point of sale (POS). This suggests an increase in the adoption of electronic payment in Nigeria. However, the question to ask is: how many account holders are getting involved in the electronic payment transactions?

Figure 2 shows the number of account holders in Nigeria. From the figure, it is clear that there are a growing number of people having account with commercial banks in the country. This also suggests that more people are having financial activities with formal financial sectors of the economy, and this indicates rising financial inclusion in the country which has been described as a major challenge in the Nigerian financial sector. In the past, this 


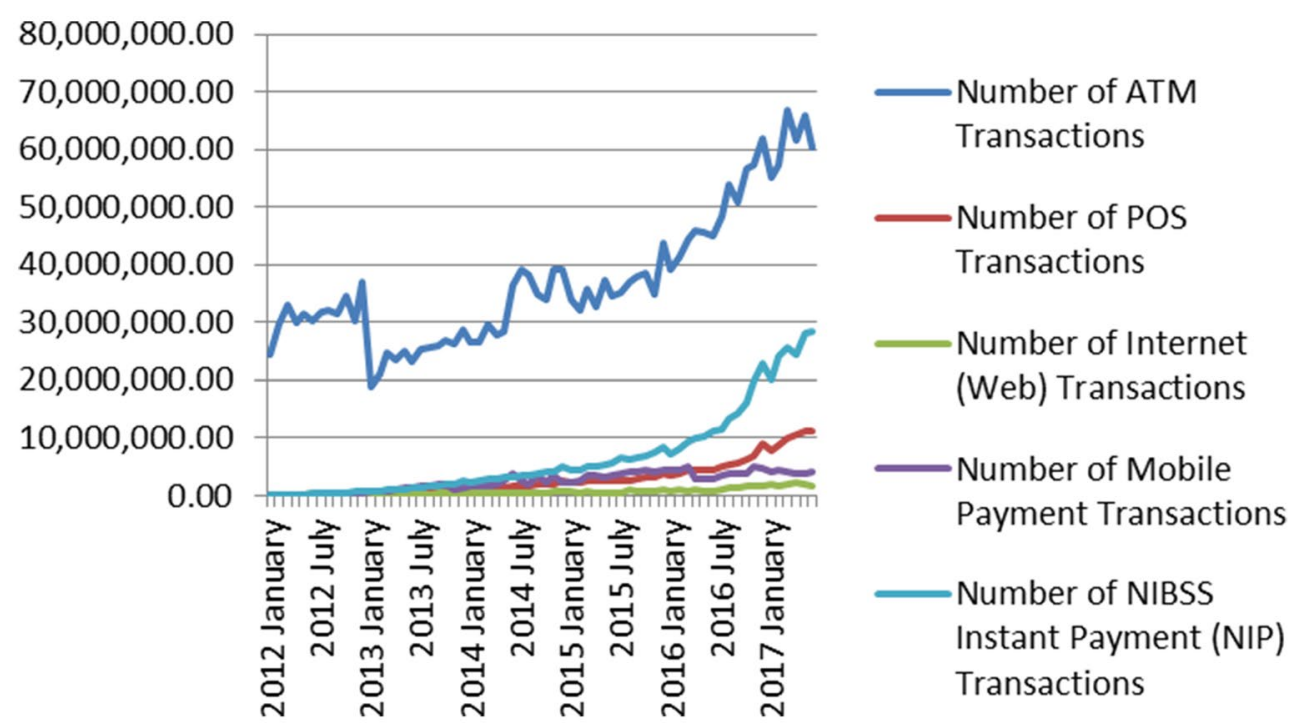

Fig. 1 Trend of various e-payment platforms in Nigeria

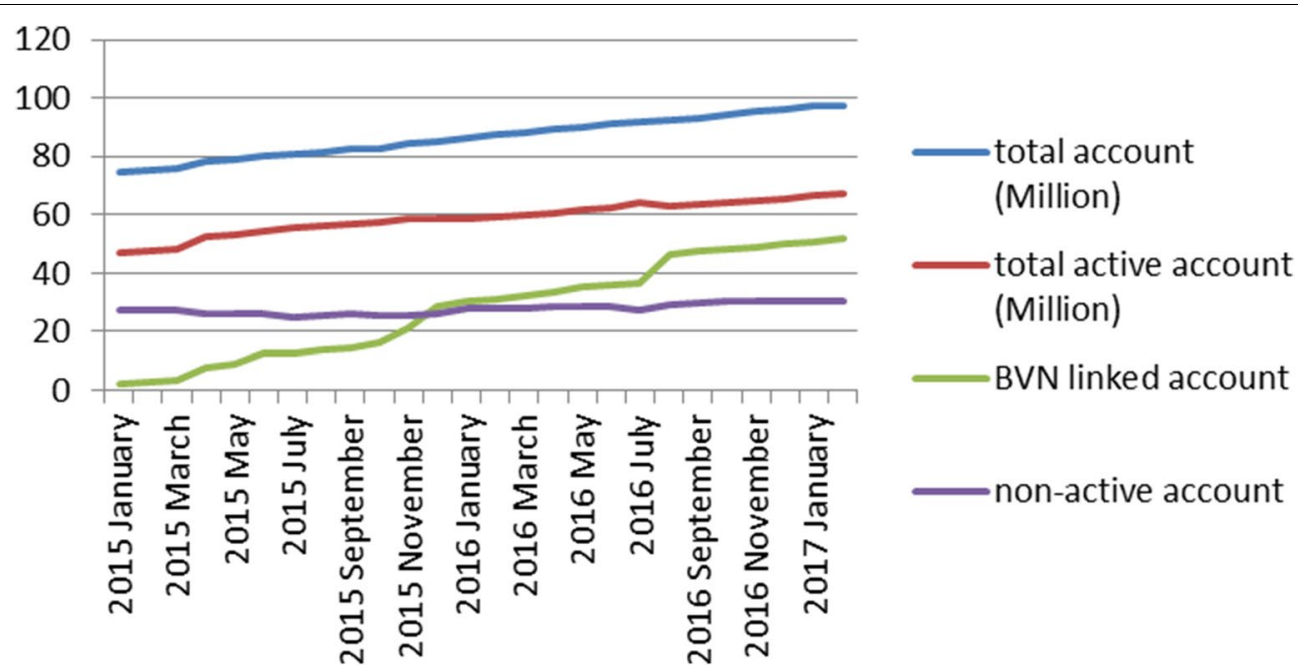

Fig. 2 Number of account holders in Nigeria. Source: Authors' Computation Based on NIBSS data (2018)

increase in the number of account holders, the number of non-active or dormant account has been on the increase moving from 27 million in 2012 to 30 million in 2017 and this will have serious implication for the measurement of financial inclusion.

Financial inclusion has been recognized as a very important factor for electronic payment adoption. In fact, it can be described as a major precondition for electronic payment adoption in any economy. Apart from mobile banking, all other electronic payment platforms require bank account in formal financial sector for smooth transactions. Thus, it is very critical to present the position of this key variable in this study. According to Enhancing Financial Innovation and Access EFInA [13], there are five major barriers to financial inclusion, namely income, physical access, financial literacy, affordability and eligibility. In a baseline survey conducted in 2008 by (EFInA), it was revealed that about 45.4 million of Nigerian adults suffer from financial exclusion, representing 52.5 of the population. A similar survey in 2016 revealed that 40.1 million adults in the country, representing $41.6 \%$ of the adult population, are still financially excluded.

The regional distribution of the exclusion is presented in Table 1 over the years. In 2012, the Northern region 
Table 1 Level of regional financial inclusion in Nigeria. Source: EFInA Access to Financial Services in Nigeria 2016 and 2017 updated survey

\begin{tabular}{|c|c|c|c|c|}
\hline Region & Finance access & 2012 & 2014 & 2016 \\
\hline Total adult population & & $13 \mathrm{~m}$ & $14 \mathrm{~m}$ & $14 \mathrm{~m}$ \\
\hline \multirow[t]{3}{*}{ North Central } & Formally included & $48 \%$ & $49 \%$ & $48 \%$ \\
\hline & Informal only & $20 \%$ & $19 \%$ & $14 \%$ \\
\hline & Financially excluded & $32 \%$ & $33 \%$ & $39 \%$ \\
\hline Total adult population & & $11 \mathrm{~m}$ & $11 \mathrm{~m}$ & $12 \mathrm{~m}$ \\
\hline \multirow[t]{3}{*}{ North East } & Formally included & $26 \%$ & $26 \%$ & $25 \%$ \\
\hline & Informal only & $15 \%$ & $5 \%$ & $14 \%$ \\
\hline & Financially excluded & $60 \%$ & $68 \%$ & $62 \%$ \\
\hline Total adult population & & $19 \mathrm{~m}$ & $21 \mathrm{~m}$ & $22 \mathrm{~m}$ \\
\hline \multirow[t]{3}{*}{ North West } & Formally included & $23 \%$ & $34 \%$ & $24 \%$ \\
\hline & Informal only & $14 \%$ & $9 \%$ & $6 \%$ \\
\hline & Financially excluded & $64 \%$ & $56 \%$ & $70 \%$ \\
\hline Total adult population & & $12 \mathrm{~m}$ & $12 \mathrm{~m}$ & $12 \mathrm{~m}$ \\
\hline \multirow[t]{3}{*}{ South East } & Formally included & $52 \%$ & $63 \%$ & $59 \%$ \\
\hline & Informal only & $22 \%$ & $11 \%$ & $13 \%$ \\
\hline & Financially excluded & $26 \%$ & $25 \%$ & $28 \%$ \\
\hline Total adult population & & $19 \mathrm{~m}$ & $20 \mathrm{~m}$ & $21 \mathrm{~m}$ \\
\hline \multirow[t]{3}{*}{ South West } & Formally included & $58 \%$ & $63 \%$ & $73 \%$ \\
\hline & Informal only & $18 \%$ & $13 \%$ & $4 \%$ \\
\hline & Financially excluded & $25 \%$ & $25 \%$ & $18 \%$ \\
\hline Total adult population & & $14 \mathrm{~m}$ & $15 \mathrm{~m}$ & $16 \mathrm{~m}$ \\
\hline \multirow[t]{3}{*}{ South-South } & Formally included & $52 \%$ & $52 \%$ & $54 \%$ \\
\hline & Informal only & $18 \%$ & $15 \%$ & $14 \%$ \\
\hline & Financially excluded & $30 \%$ & $33 \%$ & $31 \%$ \\
\hline
\end{tabular}

of the country has the highest number of financial exclusion rate, and in within this region; North West has the highest number of adults who are financial excluded. The Northern region has maintained this position over the years with little or no improvement except for the North West in 2014. The situation is getting worse in North East and North Central, though this might be attributed to the insecurity pervading the region, as a result of insurgence. The Southern region demonstrates better performance, in terms of the percentage of adult financially excluded. In the same vain, the South West has the least number of financial exclusion in the country.

\section{Review of literature}

\section{General literature review}

The increased rate and dynamics of e-commerce and e-payment in recent times have necessitated the need for studies to investigate the relationship between e-payment and consumers' spending in various countries and regions. According to Feinberg [14], electronic mode of payment will be more acceptable than the traditional mode of payment in the USA. This is also the case in developed and developing nations. Based on this, several studies have examined the relationship between electronic payment and key macroeconomic variables such as economic growth, consumer spending, inflation and unemployment, and so on. For the purpose of this study, more attention is given to literatures that discuss determinants of electronic payment adoption, consumer spending and electronic payment.

Focusing on the determinants of e-payment adoption, Gholami et al. [17] investigated the intention to adopt e-Payment in Nigeria using the Unified Theory of Acceptance and Use of Technology (UTAUT) model. The study identified perceived benefits, effort expectancy, social influence, trust, awareness and demographic variables as major factors determining intention to adopt e-payment in Nigeria. Similarly, Junadi and Sfenrianto [20] examined consumer's intention to use e-payment in Indonesia. This study also adopted Unified Theory of Acceptance and Use of Technology (UTAUT) and concludes that culture and perceived security are important factors for electronic payment adoption in that country.

Likewise, Barkhordari et al. [8] conducted a more specialized study on the important factors influencing trust in e-payments systems in Iran. The submission of the study is that technical and transaction procedures and access to security guidelines are the major factors which influence perceived trust of customers. Oney et al. [28] also examined the determinant of electronic payment system (EPS), based on consumers' personal experience in North Cyprus. Specifically, the study investigated perspectives of consumers on the security and trust and their effects on EPS. The finding of the study is that perceived security and trust significantly affects EPS adoption and usage. A micro-study by Omotayo and Dahunsi [27] focused on the factors that influence point-of-sale (POS) adoption by businesses in Ibadan and Lagos metropolis using a Multistage sampling technique. The study submitted that factors such as perceived ease of use and subjective norms significantly influence the adoption of POS, while other factors like image, characteristics of the organization and perceived usefulness do not have a significant relationship with POS machine adoption in Nigeria. Studies of this nature have also been done in developed countries. Gerarden et al. [16] grouped factors that influence e-payment adoption in two categories: the supply and demand side factors. The study reveals that all the factors (both demand and supply) have significant influence on consumer payment choice.

Considering the effect of e-payment on other variables, Altarifi et al. [6] examined e-shopping determinants and how they influence purchasing decision of consumers in Jordan. They identified three determinants of e-shopping as marketing, cultural and technological determinants. 
Using a multiple regression analysis, the study finds that the marketing determinants do not significantly influence consumer purchase decision while both technological and cultural determinants do. On his part, Trutsch [38] examined the effect of contactless payment on the spending pattern of consumers using the debit and credit cards for different transaction types at the point of sales in the US in 2010. The survey method was used to achieve this objective and the study concludes that debit and credit cards usage leads to an increase in the ratio of spending by approximately 10 and $8 \%$ respectively. Thus, any convenient and faster means of payment at the POS would motivate consumers to frequently undertake more transactions.

In Nigeria, Adebayo et al. [1] investigated the effect of e-payment options on consumer's buying behaviour in retail outlets of Ilorin metropolis. This study dwells mainly on the buying and paying experience of customers and concludes that e-payment significantly affects consumer buying experience in retail outlets in Nigeria. Similarly, Adedokun [2] examined whether e-payment methods such as mobile banking and POS services have significant impact on the financial performance of SMEs in Zaria metropolis, using the multiple regression method to analyse the data. The finding of Adedokun's study is that these innovative methods of payment have significant effect on the performance of SMEs in Zaria. On their part, Adeoti and Oshotimehin [3] discussed factors that influence the adoption of POS terminals in Nigeria using the probit model. The study reveals that factors such as convenience ease of use, security, intention to use, availability and nativity influence the use of POS terminals in Nigeria.

Literature review on security and trust issues in e-payment Starting with the review of existing literature performed by Romdhane [31], the review summarized that a secure EP system must contain nine components. These are authentication, fraud prevention, confidentiality, divisibility, transferability, duplicate spending prevention, payment privacy, payment anonymity and payer traceability. In line with this submission, study by Kalakota and Whinston [23] and Kim et al. [22] argued and submitted that technical reliability and the resistance of the e-payment against security attacks are two factors affecting the security of e-payment. In addition, Laudon and Traver [23] and Corbitt et al. [12] identified sophisticated transaction procedures and process as crucial approach to resolving perceived security and trust concerns.

The recent study by Oney et al. [28] analysed the determinants of perceived security and trust including the effect of perceived security and trust on the usage of e-payment in Northern Cyprus employing structural equation modelling (SEM). The findings from the study indicate that both perceived security and trust influence e-payment usage. They also identified technical protection and past experience as common determinants of perceived security and trust. In another study, Barkhordari et al. [8] investigated factors influencing trust in e-payments systems in Iran using factor analysis and structural equations modelling (SEM). The study submitted that perceived security and trust have positive impact on using e-payment systems. They also identified technical and transaction procedures and access to security protocols as most impotent factors on perceived trust of customers.

\section{Methodology}

This study was conducted on the basis of quantitative research methodology. It employed a mixed-method approach as influenced by the data collected through both primary and secondary sources. The primary data were obtained through a cross-sectional survey of banks' customers who have experienced the e-payment modes in Lagos state, Nigeria. The data collected mainly address the main research objective which is to evaluate what determinants the use of e-payment in Nigeria and its influence on consumer spending growth. The questionnaire was designed in line with Likert scale, ranging from (strongly disagree 1 to strongly agree 5). For validity of research instrument, factor analysis was employed for the validation of construct scale. This served in measuring the construct of e-payment factors and consumer purchase decision based on previous studies and validity. Fifty copies of the questionnaire were administered to 50 customers who are familiar and have used different modes of e-payment in the last 5 years. The copies retrieved were subjected to Cronbach alpha test of reliability. As affirmed in the reliability test (Table 2), awareness (usage) serves as the first variable with 4 items show Cronbach alpha of (0.829), convenience with 6 items (0.881), security and safety with 4 items $(0.796)$, trust with 4 items (0.725), social influence with 4 items (0.762), while the dependent variable consumer spending growth with 6 items accounted for (0.757). All variables were found to be reliable, ranging between 0.725 and 0.828 . The Cronbach alpha values are within the acceptable limit $[18,26,28,30]$. Hence, the study scale items of the six identified variables are immensely reliable and satisfactory. The population comprises all users of e-payment modes of financial transaction in Lagos, which is estimated to be very large. Considering the infinite nature of the population of the study and absence of sampling frame, Cochran's [11] method was used to determine the sample size 
Table 2 Kaiser-Meyer-Olkin, Bartlett's and reliability tests of sampling and variables. Source: Pilot Study, 2018

\begin{tabular}{|c|c|c|c|}
\hline \multicolumn{3}{|c|}{ Kaiser-Meyer-Olkin measure of sampling adequacy } & .790 \\
\hline \multicolumn{3}{|c|}{ Approx. chi square } & 6638.719 \\
\hline \multicolumn{3}{|c|}{ Bartlett's test of sphericity DF } & 378 \\
\hline \multicolumn{3}{|l|}{ Sig. } & .000 \\
\hline SN & Study variables & Items & $\begin{array}{l}\text { Cronbach } \\
\text { alpha } \\
\text { coefficient }\end{array}$ \\
\hline 1 & Awareness (usage) & 4 & 0.829 \\
\hline 2 & Convenience & 6 & 0.881 \\
\hline 3 & Security and safety & 4 & 0.796 \\
\hline 4 & Trust & 4 & 0.725 \\
\hline 5 & Social influence & 4 & 0.762 \\
\hline 6 & Consumers'spending growth & 6 & 0.757 \\
\hline
\end{tabular}

$$
n_{0}=\frac{Z^{2} * p *(1-p)}{e^{2}}
$$

where $n_{0}$ is sample size, $Z$ is the abscissa of the normal curve that cuts off an area $\alpha$ at the tails (e.g. 1.96 for a $95 \%$ confidence level), e is the acceptable sampling error, $\mathrm{p}$ is the estimated proportion of an attribute that is present in the population, and $q=1-p$. Therefore, the e-payment customers sample size of the study at $95 \%$ confidence level and $1 \%$ precision is denoted by; $Z=1.96, p=(0.5$ maximum variability assumed), since actual variability in the proportion is not known), $q=0.5 ; e=0.05$. Hence, the sample size of the study is computed as follows;

$$
n_{0}=\frac{(1.96)^{2}(0.5)(0.5)}{(0.05)^{2}}=384.16
$$

The sample size for this study, as determined through Cochran formulae, is 384. Furthermore, the KaiserMeyer-Olkin (KMO) test for sampling adequacy was used with result of 0.790 , which affirmed satisfactory and therefore can be recognized (accepted). At ninety-five per cent (95\%) level of significance, $\alpha=0.05$; the $p$ value (Sig.) of 0.000 is less than $(<) 0.05$, therefore researchers factor analysis is effective in this study. The Bartlett's test also recognized as additional sign of the strength of the connection or relationship among research variables was conducted which affirmed that the Bartlett's test of sphericity is significant $(0.000)$. That is, significance is less than 0.05 . Thus, the significance level is small enough not to support the null hypothesis. This means that correlation matrix is not an identity matrix. Thereafter, the instrument of data collection was administered on 420 respondents, using the multistage sampling technique to sample respondents across five divisions (locations) of Lagos. This is necessary, as only those who have used the e-payment modes of transaction can provide reliable information on its attributes. It is also necessary to ensure representativeness. Thus, questionnaire was purposively administered to some Nigerian who have been using different e-payment services mode (ATM, POS, instant payment, internet banking, mobile money) in last the 5 years. A total of 401 copies of the questionnaire representing ninety-five point five per cent $(95.47 \%)$ rate of returned were retrieved and certified valid for analysis. The data were analysed using descriptive (frequency and percentage) and inferential statistics (Pearson correlation, Hierarchical regression analysis and analysis of variance).

\section{Results and discussion}

Table 3 shows the factors arranged according to their level of importance, that is, factor one (1) is considered more essential than factor two (2); factor two (2) is assumed to be more important than factor three (3), factor three (3) is more dynamic than factor four (4) and so on. More so, the variance percentage of factor one (1) as well as factor are observed as the highest variance as compared with factor three (3), four (4), five (5), and so forth. Thus, all the factor loadings are meaningful as they are greater than 0.4 [13].

Table 4 displays the socio-demographic characteristics and personal data of the respondents, showing their sex (gender), age, marital status, highest academic qualification, occupation status, year of experience and monthly income. The male respondents were more than their female counterparts by $33.2 \%$ (male: $66.6 \%$; female: $33.4 \%$ ). A total of $44.4 \%$ were below 30 years, $40.6 \%$ within the age of $30-40$ years, $11.5 \%$ were within the age range of $41-50$ years and $3.5 \%$ were aged $51-60$ years. This indicates the level of maturity among the respondents. In addition, $53.4 \%$ were single while $46.6 \%$ were married. There are also more single youth (adults) that are very conversant with information technology development, especially as it relates to finance. In the same manner, the educational qualification of the respondents shows that $52.6 \%$ of them had higher education (bachelor degree holders). Similarly, more than one-third (46.1\%) of the respondents had MBA/M.Sc. (master degree holders) while $1.2 \%$ that is, 5 of the participants had $\mathrm{PhD}$ (Doctor of Philosophy) degree. This implies that the study's respondents were mainly those with a high level of a formal educational qualification.

In terms of respondents' jobs status, the first set of respondents $(62.6 \%)$ recognized with white-collar job followed by $12.5 \%$ who claimed to be job seekers (unemployed), $11.7 \%$ were students, $10.5 \%$ were blue-collar respondents, such as artisans and entrepreneurs, just as 
Table 3 Summary of percentage of variance and loading of items. Source: Extracted by Authors, 2018

\begin{tabular}{|c|c|c|}
\hline Factors & Percentage of variance & Loading \\
\hline Awareness & 32.771 & \\
\hline I am aware of different e-payment modes in Nigeria & & .799 \\
\hline I use the e-payment modes than cash in most transactions & & .647 \\
\hline Information on the usage of e-payment is readily available, even on social media & & .677 \\
\hline It is easy for me to become skillful at using any e-payment mode & & .712 \\
\hline Convenience & 9.035 & \\
\hline I access financial information through mobile computing devices & & .755 \\
\hline I have a feeling of happiness when using e-payment systems & & .751 \\
\hline Frustration of banking hall transaction congestion is reduced & & .622 \\
\hline Limit of cash movement & & .511 \\
\hline Adaptability of e-payment systems with mobile phone is appreciated by me & & .882 \\
\hline Effective transaction through e-payment is less time consuming & & .849 \\
\hline Security and safety & 6.534 & \\
\hline Risk of physical cash movement is higher than through electronic mode & & 609 \\
\hline Keeping cash in anticipation for financial transaction is better electronically & & .553 \\
\hline I feel secured making transaction on any of the e-payment mode & & .715 \\
\hline e-payment systems guarantee consumers' privacy of financial consumption & & .466 \\
\hline Trust & 5.282 & \\
\hline e-payment systems is reliable for financial transaction & & .617 \\
\hline e-payment system is vulnerable to system intruders or hackers & & .489 \\
\hline I am comfortable with financial services delivery of e-payment system in Nigeria & & .479 \\
\hline I trust e-payment systems as it send money to correct recipients & & .583 \\
\hline Social influence & 5.171 & \\
\hline I use e-payment modes, because most of my friends uses it & & .502 \\
\hline The trend in the society facilitates my usage of e-payment & & .530 \\
\hline I feels, it is professional to use e-payment systems in financial transactions & & .362 \\
\hline My family are using the e-payment modes & & .352 \\
\hline Consumers'spending growth & 4.492 & \\
\hline With so many payment channels, my spending appears to have increased & & .528 \\
\hline e-payment systems facilitate transaction across borders & & .571 \\
\hline Purchase decision is quicker with the adoption of e-payment system & & .560 \\
\hline e-payment systems simplifies consumption mobility at any time or place & & .681 \\
\hline e-payment makes me buy things I would not have bought ordinarily & & .495 \\
\hline With e-payment, I spend higher percentage of my income on consumption & & .579 \\
\hline
\end{tabular}

other status formed $2.7 \%$. Regarding the respondents' year of experience, those who indicated that they had worked currently for up to 5 years instituted the majority of the respondents (50.6\%), followed by those who specified that they had worked for six to ten $(6-10)$ years (43.4\%) while $6.0 \%$ had $11-15$ years of work experience. Low level of working experience was attributed to the age of most of the respondents.

On a final note, the respondents' monthly income ranged from $89,999(90,000)$ to $599,999(600,000)$. Most of the respondents (46.6\%) indicated that their monthly income was within 90,000-199,999, followed by $35.9 \%$ whose monthly income is $89,999.13 .7 \%$ of the respondents were identified with monthly income ranging from 200,000 to 399,999, while 3.7\% earned between 400,000 to 599,999 as their monthly income.

Table 5 shows that the adjusted $R$-square is 0.621 , indicating that the independent variables (social influence, convenience, trust, security and safety) accounted for $62.1 \%$ variations in the dependent variable, which is adoption of e-payment systems by consumers in Nigeria, while the rest are explained by other variables aside these variables. F-statistic (164.923) shows overall significance of model; as the $F$-statistic is significant at $5 \%$ level. The probability of its value 0.000 is less than the 0.05 critical levels. We can therefore affirm that the test 
Table 4 Socio-Demographic Characteristics and Personal Data of the Respondents. Source: Survey, 2018

\begin{tabular}{|c|c|c|}
\hline & Frequency & Per cent \\
\hline \multicolumn{3}{|c|}{ Sex of the respondents } \\
\hline Male & 267 & 66.6 \\
\hline Female & 134 & 33.4 \\
\hline Total & 401 & 100.0 \\
\hline \multicolumn{3}{|c|}{ Age distribution of the respondents } \\
\hline Below 30 years & 178 & 44.4 \\
\hline $30-40$ years & 163 & 40.6 \\
\hline $41-50$ years & 46 & 11.5 \\
\hline $51-60$ years & 14 & 3.5 \\
\hline Total & 401 & 100.0 \\
\hline \multicolumn{3}{|c|}{ Marital status of the respondents } \\
\hline Single & 214 & 53.4 \\
\hline Married & 187 & 46.6 \\
\hline Total & 401 & 100.0 \\
\hline \multicolumn{3}{|c|}{ Respondents highest academic qualification } \\
\hline Graduate & 211 & 52.6 \\
\hline MBA/M.Sc. & 185 & 46.1 \\
\hline $\mathrm{PhD}$ & 5 & 1.2 \\
\hline Total & 401 & 100.0 \\
\hline \multicolumn{3}{|c|}{ Occupation status of the respondents } \\
\hline White collar & 251 & 62.6 \\
\hline Blue collar & 42 & 10.5 \\
\hline Students & 47 & 11.7 \\
\hline Job seekers & 50 & 12.5 \\
\hline Others & 11 & 2.7 \\
\hline Total & 401 & 100.0 \\
\hline \multicolumn{3}{|c|}{ Respondents year of experience } \\
\hline Below 5 years & 203 & 50.6 \\
\hline $6-10$ years & 174 & 43.4 \\
\hline $11-15$ years & 24 & 6.0 \\
\hline Total & 401 & 100.0 \\
\hline \multicolumn{3}{|c|}{ Respondents monthly income } \\
\hline Below-89,999 & 144 & 35.9 \\
\hline $90,000-199,999$ & 187 & 46.6 \\
\hline 200,000-399,999 & 55 & 13.7 \\
\hline $400,000-599,999$ & 15 & 3.7 \\
\hline Total & 401 & 100.0 \\
\hline
\end{tabular}

is statistically significant and the model can be used for further evaluation. Coefficients of each variable affirm that there is a significant positive relationship between convenience and adoption of e-payment system with significant level of 0.0000 . It also indicates that there is a significant positive influence of security and safety on adoption of e-payment system by household consumers with significance value of 0.0000 , which reveals that security and safety have strongly influenced e-payment system adoption by consumers.
Moreover, result acknowledges insignificant relationship between trust and e-payment adoption with insignificance value of 0.797 , implying that e-payment adoption in Nigeria does not significantly depend on consumer trust, but on safety, security and convenience. Additionally, the result of insignificant statistical influence of social influence on e-payment adoption with the $p$ value of 0.803 implies that social influence is not a determinant factor of e-payment adoption in Nigeria, as postulated previous studies although before the cashless policy implementation [17]. Lastly, the results show that there is a positive significant relationship between electronic payment systems determinants (convenience, security and safety, trust, social influence) and e-payment adoption in Nigeria, with these variables accounted for more than half $(3 / 5)$ of what influences household consumer to adopt e-payment mode of transaction in Nigeria.

Table 6 shows that the adjusted $R$-square is 0.262 , implying that social influence, awareness, trust, security and safety, and convenience explained $26.2 \%$ variations in consumers' spending growth, while the rest are explained by the other variables aside the electronic payment factors. F-statistic (29.474) of ANOVA result recognizes significance of the model. The $F$-statistic is significant at $5 \%$ level and its probability value 0.000 is below 0.05 critical levels. Hence, the study affirmed that the test is statistically significant. The e-payment factors coefficients affirm that there is a significant positive relationship between awareness and consumers' spending growth. It also shows insignificant relationship between convenience and consumers' spending growth with significance value of 0.244 , indicating that convenience has no significant impact on consumers' spending growth in Nigeria. This implies that no matter how convenient the e-payment mode may be, it does make the consumer spend irrationally. Consumers are shown to be rational in spending.

Similarly, insignificant relationship between security and safety and consumers' spending growth with insignificance value of 0.452 was acknowledged. This shows that security and safety do not determine the level of consumers' spending growth in Nigeria. Furthermore, significant positive relationship was found between trust and consumers' spending growth, with the $p$ value of 0.001 . This indicates that trust is a predominant factor to determine the level of consumers' spending growth of e-payment in Nigeria as demonstrated in the analysis. Finally, the study recognized that there is a positive significant relationship between social influence and consumers' spending growth in Nigeria. Therefore, electronic payment factors such as awareness, convenience, security and safety, trust 
Table 5 Regression analysis of determinant of e-payment adoption. Source: Author's computation (2018)

\begin{tabular}{|c|c|c|c|c|c|}
\hline \multirow{2}{*}{$\begin{array}{l}\text { Model summary } \\
1\end{array}$} & $R$ & $R$-square & Adjusted $R$-square & \multicolumn{2}{|c|}{ Std. error of the estimate } \\
\hline & $.791^{\mathrm{a}}$ & .625 & .621 & .58823 & \\
\hline ANOVA & Sum of squares & $d f$ & Mean square & $F$ & Sig. \\
\hline \multicolumn{6}{|l|}{1} \\
\hline Regression & 228.266 & 4 & 57.067 & 164.923 & $.000^{\mathrm{a}}$ \\
\hline Residual & 137.023 & 396 & .346 & & \\
\hline Total & 365.289 & 400 & & & \\
\hline \multirow[t]{2}{*}{ Coefficients $^{b}$} & \multicolumn{2}{|c|}{ Unstandardized coefficients } & Standardized coefficients & $t$ & Sig. \\
\hline & B & SE & Beta & & \\
\hline \multicolumn{6}{|l|}{1} \\
\hline (Constant) & -.008 & .192 & & -.043 & .966 \\
\hline Convenience & .770 & .048 & 678 & 16.131 & .000 \\
\hline Security and safety & .195 & .053 & .151 & 3.704 & .000 \\
\hline Trust & .013 & .051 & .010 & .257 & .797 \\
\hline Social influence & .011 & .043 & .008 & .250 & .803 \\
\hline
\end{tabular}

a Predictors: (constant), social influence, convenience, trust, security and safety

b Dependent variable: e-payment adoption

Table 6 Influence of e-payment factors on consumers' spending growth. Source: Author's computation (2018)

\begin{tabular}{|c|c|c|c|c|c|}
\hline Model summary & $R$ & $R$-square & Adjusted $R$-square & & SE of the estimate \\
\hline 1 & $.521^{\mathrm{a}}$ & .272 & .262 & & .64760 \\
\hline ANOVA & Sum of squares & $d f$ & Mean square & $F$ & Sig. \\
\hline \multicolumn{6}{|l|}{1} \\
\hline Regression & 61.805 & 5 & 12.361 & 29.474 & $.000^{\mathrm{a}}$ \\
\hline Residual & 165.655 & 395 & .419 & & \\
\hline Total & 227.460 & 400 & & & \\
\hline \multirow[t]{2}{*}{ Coefficients $^{\mathbf{b}}$} & \multicolumn{2}{|c|}{ Unstandardized coefficients } & Standardized coefficients & $t$ & Sig. \\
\hline & B & SE & Beta & & \\
\hline \multicolumn{6}{|l|}{1} \\
\hline (Constant) & 1.323 & .212 & & 6.247 & .000 \\
\hline Awareness & .225 & .055 & .285 & 4.060 & .000 \\
\hline Convenience & .079 & .068 & .088 & 1.168 & .244 \\
\hline Security and safety & -.044 & .059 & -.044 & -.752 & .452 \\
\hline Trust & .189 & .057 & .179 & 3.330 & .001 \\
\hline Social influence & .182 & .047 & .182 & 3.859 & .000 \\
\hline
\end{tabular}

a Predictors: (constant), social influence, awareness (usage), trust, security and safety, convenience

b Dependent variable: consumers' spending growth

and social influence have statistical significant influence on consumer/household spending growth in Nigeria.

In the hierarchical regression analysis in Table 10 ("Appendix"), the predictors (academic qualification, occupation status, year of experience, sex, marital status, as well as age) were observed for collinearity (that is, a situation in which a predictor variable in a multiple regression model can be forecast from others with a considerable degree of correctness (accuracy). As the regression table shows, seven socio-demographic variables were entered in step 1 . Consumers' spending growth was taken as dependent variable. Monthly income was used 
in step 2. The model summary table shows the percentage of variability in the dependent variable that can be accounted for by all the predictors (that is, the interpretation of $R$-square). The change in $R^{2}$ ( $R$-square) assesses how much predictive power was more (added) to the model by the addition of another variable in step 2 . Thus, the percentage of variability accounted for decreased from 11.2 to $11.0 \%$.

The ANOVA table confirms study doubts: The first model (demographic variables alone) and the second model (demographics plus monthly income) projected (predicted) scores on the dependent variable (consumers' spending growth) are statistically significant based on the result, since the $p$ values $(0.000)$ is less 0.05 . The first set of predictors (seven socio-demographic variables) was significant, and the second (monthly income) was similarly substantial. This means that income has an effect on consumers' spending growth and beyond the effects of demographics. Fortunately, all of the predictors are statistically significant.

The "coefficients" table here is advantageous if some of these studies predictors were statistically significant. Hence, some were significant, the coefficients are interpretable. Sex is statistically significant with value of (0.002); occupation status with the value of 0.000 . Two of the socio-demographic characteristics (predictors), sex and occupation status, were statistically significant. All others demographic predictors such as (highest academic qualification, year of experience, marital status, age) were not statistically significant. This indicates that consumer spending growth in Nigeria is gender income sensitive.

In Table 7, the results of the Pearson correlation computation are shown. The highlighted Pearson correlations that are significant with one star specifying significant correlation at 5 per cent (\%) level, while two stars specify that correlation is significant at 1 per cent (\%). The Pearson correlation coefficient is $\left(0.432^{* *}\right)$, while the $\mathrm{p}$ value is 0.000 . This implies that there is a significant positive relationship between awareness and consumers' spending growth in Nigeria, since $p$ value (0.000) is less than 0.01 . This is established by the result which was flagged with two stars. The Pearson correlation coefficient is $\left(.402^{* *}\right)$, while the $\mathrm{p}$ value is 0.000 . Hence, there is a significant positive relationship between convenience and consumers' spending growth in Nigeria with significance $p$ value $(0.000)$ below 0.01 . Furthermore, the Pearson correlation result $\left(0.301^{* * *}\right)$ avowed that there is a significant relationship between security and safety and consumers' spending growth in Nigeria with significance $p$ value $(0.000)<0.01$.

In addition, the result of Pearson correlation $\left(0.395^{* *}\right)$ acknowledged that there is a significant relationship between trust and consumers' spending growth in Nigeria with significance $p$ value $(0.000)<0.01$. Finally, a significant correlation between social influence and consumers' spending growth in Nigeria $\left(0.307^{* * *}\right)$ was established with significance $p$ value $(0.000)$ less than 0.01 . Thus, Pearson correlation matrix table affirmed that the determinants of electronic payment systems are positively allied with consumers' spending dynamics in Nigeria.

In Table 8, the study participants' spending growth was examined with several socio-demographic characteristics, such as sex, age, marital status, highest academic qualification, respondents' job status, year of experience and monthly income level. The difference of the group mean in the socio-demographic variables above indicated a significant variation (difference) at probability significance of less than 0.01 . The study's outcomes acknowledged a significant variation amid consumer spending growth and each of the sociodemographic characteristic variables: sex: sum of square (89.222), mean square (1.306), $F$ (7.467), $p$ (0.000); age: sum of square (253.027), mean square (5.216), $F$ (12.157), $p$ (0.000); marital status: sum of square (99.796), mean square (1.215), $F$ (5.877), $p$ (0.000); highest academic qualification: sum of square (110.175), mean square (1.028), $F$ (4.246), $p$ (0.000); occupation

Table 7 Correlational matrix on e-payment attributes and consumer spending growth. Source: Author's computation (2018)

\begin{tabular}{|c|c|c|c|c|c|c|}
\hline Variables & $\begin{array}{l}\text { Consumers' } \\
\text { spending growth }\end{array}$ & Awareness & Convenience & $\begin{array}{l}\text { Security } \\
\text { and safety }\end{array}$ & Trust & $\begin{array}{l}\text { Social } \\
\text { influence }\end{array}$ \\
\hline Consumers'spending growth & 1 & & & & & \\
\hline Awareness & $.432^{* *}$ & 1 & & & & \\
\hline Convenience & $.402^{* *}$ & $.781^{* *}$ & 1 & & & \\
\hline Security and safety & $.301^{* *}$ & $.591^{* *}$ & $.638^{* *}$ & 1 & & \\
\hline Trust & $.395^{* *}$ & $.414^{* *}$ & $.492^{* *}$ & $.444^{* *}$ & 1 & \\
\hline Social influence & $.307^{* *}$ & $.164^{* *}$ & $.173^{* *}$ & $.222^{* *}$ & $.405^{* *}$ & 1 \\
\hline
\end{tabular}

${ }^{* *}$ Correlation is significant at the 0.01 level (two-tailed) 
Table 8 Analysis of variance of socio-economic variables of respondents. Source: Author's computation (2018)

\begin{tabular}{|c|c|c|c|c|c|}
\hline & Sum of squares & $d f$ & Mean square & $F$ & Sig. \\
\hline \multicolumn{6}{|l|}{ Sex } \\
\hline Between groups & 22.209 & 17 & 1.306 & 7.467 & .000 \\
\hline Within groups & 67.013 & 383 & .175 & & \\
\hline Total & 89.222 & 400 & & & \\
\hline \multicolumn{6}{|l|}{ Age } \\
\hline Between groups & 88.679 & 17 & 5.216 & 12.157 & .000 \\
\hline Within groups & 164.348 & 383 & .429 & & \\
\hline Total & 253.027 & 400 & & & \\
\hline \multicolumn{6}{|l|}{ Marital status } \\
\hline Between groups & 20.648 & 17 & 1.215 & 5.877 & .000 \\
\hline Within groups & 79.147 & 383 & .207 & & \\
\hline Total & 99.796 & 400 & & & \\
\hline \multicolumn{6}{|c|}{ Highest academic qualification } \\
\hline Between groups & 17.470 & 17 & 1.028 & 4.246 & .000 \\
\hline Within groups & 92.704 & 383 & .242 & & \\
\hline Total & 110.175 & 400 & & & \\
\hline \multicolumn{6}{|l|}{ Occupation status } \\
\hline Between groups & 203.873 & 17 & 11.993 & 12.070 & .000 \\
\hline Within groups & 380.556 & 383 & .994 & & \\
\hline Total & 584.429 & 400 & & & \\
\hline \multicolumn{6}{|l|}{ Year of experience } \\
\hline Between groups & 21.269 & 17 & 1.251 & 3.808 & .000 \\
\hline Within groups & 125.828 & 383 & .329 & & \\
\hline Total & 147.097 & 400 & & & \\
\hline \multicolumn{6}{|l|}{ Monthly income } \\
\hline Between groups & 24.666 & 17 & 1.451 & 2.463 & .001 \\
\hline Within groups & 225.654 & 383 & .589 & & \\
\hline Total & 250.319 & 400 & & & \\
\hline
\end{tabular}

status: sum of square (584.429), mean square (11.993), $F$ (12.070), $p$ (0.000); year of experience: sum of square (147.097), mean square (1.251), $F$ (3.808), $p$ (0.000); and monthly income: sum of square (250.319), mean square (1.451), $F$ (2.463), $p$ (0.001). In addition, a combination of socio-demographic factors (predictors), as affirmed in the above ANOVA table, offers a foundation for an understanding of consumers' spending dynamics in Nigeria, so as to loosen policy implications on household consumption. Thus, consumers' spending growth here is affirmed as dependent variable.

\section{ARDL model estimation}

In a bid to validate results obtained from primary source, we obtained monthly data on households' consumptions over a period of 5 years (2012-2017). We went on to examine the effect of e-payment variables (POS, Internet and mobile transactions) on households' consumptions using Autoregressive Distributed Lag (ARDL). The reason for this method of estimation is anchored on its ability to handle expected endogeneity problems in the model. The estimated model is specified in Eq. (1) below.

$$
\begin{aligned}
\Delta \ln \operatorname{HOUSE}_{t}=\lambda_{0} & +\sum_{j=1}^{n 1} a_{j i} \Delta \operatorname{House}_{(t-1)-j} \\
& +\sum_{j=1}^{n 2} b_{j i} \Delta M O B I L E_{t-j}+\sum_{j=1}^{n 3} c_{j i} \Delta \operatorname{INTERNET}_{t-j} \\
& +\theta_{1} \text { MOBIL }_{t=1}+\theta_{2} \operatorname{INTERNET}_{t=1}+\varepsilon_{t}
\end{aligned}
$$

In Eq. (1), HOUSE represents household consumptions, $M O B I L E$ stands for number of mobile transaction and INTERNET goes for the number of all web-based transactions. We restrict ourselves to these two variables to prevent multicollinearity problem in our model because the results from correlation show high correlation coefficients among e-payment variables. Also, we introduced all the variables at difference, because they are only stationary at first difference based on unit root tests results.

The results of ARDL model estimated are presented in Table 9. The results show that mobile transaction as a form of e-payment has statistically significant positive effect on household consumption growth, both in the short run and long run. Likewise, the internet transaction has positive effect on household. However, such effect is not statistically significant.

\section{Conclusion}

Research contribution and implications

This study concludes that educational attainment, financial inclusion, income level, internet service availability, awareness, trust, social influence, safety, security and convenience constitute major determinants of e-payment adoption. Thus, it is important to increase the trust of an average customer involve in financial transaction using electronic means in order to increase the e-payment adoption rate in Nigeria. The finding of this study is line with those of Adeoti and Oshotimehin [3]. Importantly, it

Table 9 Short-run and long-run coefficient of ARDL model. Source: Author's computation (2018)

\begin{tabular}{llllll}
\hline & dInMOBILE & dInINTERNET & CointEq(- 1) & InMOBILE & InINTERNET \\
\hline $\begin{array}{l}\text { Dependent } \\
\text { dlnHOUSE }\end{array}$ & $0.06(0.02)^{* *}$ & $0.06(0.48)^{*}$ & $-0.40(0.00)^{* *}$ & $0.15(0.02)^{* *}$ & $0.07(0.45)$ \\
\hline$* * * * * *$ indicate
\end{tabular}

***,*** indicate significant at $1 \%, 5 \%$ and $10 \%$ 
is inferable from the study that e-payment can influence purchase decision of individuals and ultimately increase households' consumptions in Nigeria. This conforms to Adebayo, Osanyinlusi and Adekeye [1] findings for Ilorin metropolis. Based on these outcomes, monetary authorities can leverage on e-payment mechanism to promote financial inclusion in an effort to enhance monetary policy effectiveness.

Additionally, this study also offered basis to realize that an average consumer in Nigeria is a rational decision maker. That is his/her spending growth is majorly influenced by awareness of various derivatives of e-payment, trust in the ability of the e-payment system to deliver as expected and social status in the society. This corroborates the findings of Oney et al. [28] and Barkhordari et al. [8] that identify awareness and trust as important factors influencing e-payment adoption. Financial sector stakeholders can work around these statistically significant factors (awareness, trust and social influence) to drive effective demand towards investments in the critical sectors of the economy.

The survey result also suggested positive and statistically significant relationship between the variables, which are not high to suggest irrelevant of any of the variables used in the study. The moderate relationships of each of the variables suggest their independence for meaningful inference of the prediction model. Thus, the determinants of electronic payment systems (awareness, convenience, safety and security, trust and social influence) are positively allied with consumers' spending dynamics in Nigeria.

Bank managers should formulate marketing and organizational strategies around the variables that statistically significant to further encourage more adopters of e-payment systems. This, in the long run, would help to decongest the banking hall and ATM point thereby facilitating good customers' spending experience, financial and inclusion for economy growth.

\section{Research limitation and future works}

One of the major limitations of survey research used in this study is that it does not account for the trend in the usage (adoption) of e-payment modes for individual and organizational financial transactions. However, this was catered for by the aggregate trend analysis performed for the country as whole (Fig. 1). The changes in population in relation to the adoption of e-payment and consumer spending dynamics which survey cannot equally monitored periodically were properly captured through trend analysis and the analysis of the regional financial inclusion levels in the country (Table 1). Another limitation of survey research is the lack of funding necessary to carry out a survey in every state of the federation. Moreover, with the sample size greater than 384 respondents in Lagos state which is the commercial nerve centre of the country, the arguments of scholars suffice that once the population is very large, that is above $10,000,000$, a sample of 384 is good enough [23,32]. With the number researchers in this study, we are able implement a good sample plan that accommodate all the five divisions of Lagos state in administration the research instruments, thereby ensuring selection of sample that is representative of the population.

\section{Abbreviations}

POS: Point-of-sale machines; CBN: Central Bank of Nigeria; ICT: Information and communication technology; ATM: Automated teller machine; NIP: Instant payment; EFInA: Enhancing financial innovation and access; UTAUT: Unified Theory of Acceptance and Use of Technology; KMO: Kaiser-Meyer-Olkin; ANOVA: Analysis of variance; ARDL: Autoregressive distributed.

\section{Acknowledgements}

Not applicable.

\section{Authors' contributions}

LOO introduced the topic, drafted the introduction, analysed the secondary data, concluded the study and discussed policy implications of our findings. BSA reviewed extant studies on electronic payment. SOA was instrumental to collection and analysis of primary data. All authors have read and approved the manuscript.

\section{Funding}

No funding was obtained for this study.

\section{Availability of data and materials}

Datasets used and/or analysed during the current study are available from the corresponding author on reasonable request.

\section{Competing interests}

The authors declare that they have no competing interests.

\section{Author details}

${ }^{1}$ Economics Unit, Distance Learning Institute, University of Lagos, Lagos, Nigeria. ${ }^{2}$ Business Administration Department, Faculty of Management Sciences, University of Lagos, Lagos, Nigeria.

\section{Appendix}

See Table 10. 
Table 10 Hierarchical regression analysis for socio-demographic variables mediation

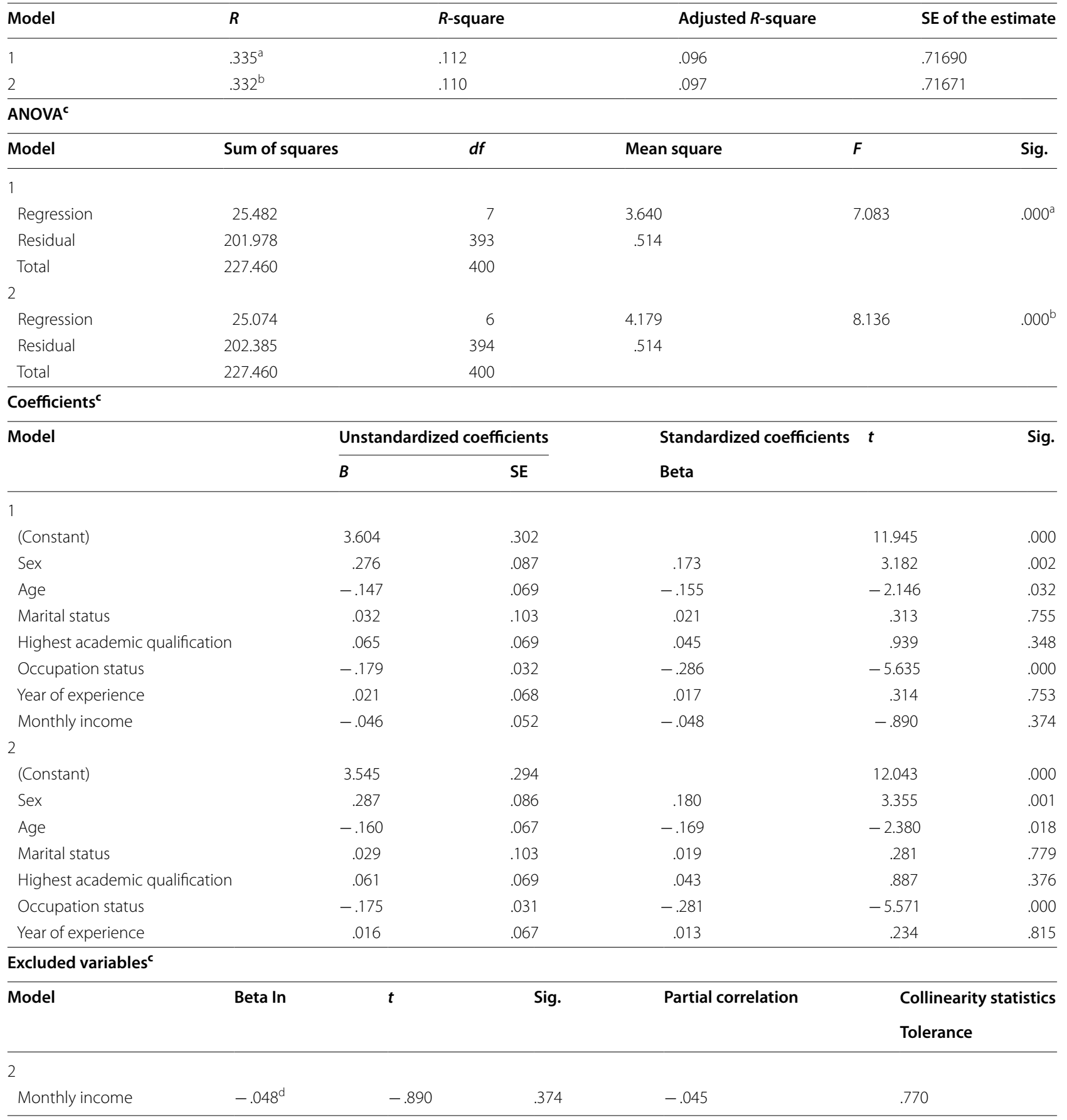

a Predictors: (constant), monthly income, highest academic qualification, occupation status, year of experience, sex, marital status, age

b Predictors: (constant), highest academic qualification, occupation status, year of experience, sex, marital status, age

c Dependent variable: consumers' spending growth

d Predictors in the model: (constant), highest academic qualification, occupation status, year of experience, sex, marital status, age 
Received: 5 February 2020 Accepted: 26 February 2020

Published: 18 March 2020

\section{References}

1. Adebayo PO, Osanyinlusi GE, Adekeye AO (2017) Impact of E-payment system on buying behaviour: evidence from retail outlets in llorin metropolis, Nigeria. International Journal of Research in Arts and Social Sciences. 9(2):137-152

2. Adedokun R (2017) The effect of cashless banking on the financial performance of small and medium scale enterprises. International Journal of Advanced Research in Public Policy, Social Development and Enterprise Studies 2(2):133-142

3. Adeoti $\mathrm{OO}$, Oshotimehin $\mathrm{KO}$ (2011) Factors influencing consumers'adoption of point of sale terminals in Nigeria. Journal of Emerging Trends in Economics and Management Sciences 2(5):388-392

4. Agbaje O, Ayanbadejo K (2013). Electronic payment and economic growth in Nigeria. A report by RTC Advisory Services Ltd

5. Al-Somali SA, Gholami R, Clegg B (2009) An investigation into the acceptance of online banking in Saudi Arabia. Technovation 29(2):130-141

6. Altarifi S, Al-Hawary SIS, AI Sakkal MEE (2015) Determinants of E-Shopping and its effect on consumer purchasing decision in Jordan. International Journal of Business and Social Science 6(1):81-92

7. Asaolu TO, Ayoola TJ, Akinkoye EY (2011) Electronic payment system in Nigeria: implementation, constraints and solutions. Journal of management and Society 1(2):16-21

8. Barkhordari M, Nourollah Z, Mashayekhi H, Mashayekhi Y, Ahangar MS (2017) Factors influencing adoption of e-payment systems: an empirical study on Iranian customers. IseB 15(1):89-116

9. Central Bank of Nigeria (CBN) (2011) Towards a cashless Nigeria: tools \& strategies. Nigerian Journal of Economy. 3(2):344-350

10. Chatterjee P, Rose RL, Sinha J (2013) Why money meanings matter in decisions to donate time and money. Marketing Letters 24(2):109-118

11. Cochran WG (1963) Sampling techniques. Wiley, New York

12. Corbitt B, Lawrence E, Newton S (2002) Electronic payment systems. In: Technology of internet business, pp 212-240

13. E F Innovation Access (EFInA) (2010) Access to financial services in Nigeria 2010 Survey

14. Feinberg RA (1986) Credit cards as spending facilitating stimuli: a conditioning interpretation. Journal of consumer research 13(3):348-356

15. Fernandes $L$ (2013) Security and trust in electronic business transactions - a study in middle-east. ZENITH International Journal of Multidisciplinary Research 3(2):142-148

16. Gerarden TD, Newell RG, Stavins RN (2017) Assessing the energy-efficiency gap. Journal of Economic Literature 55(4):1486-1525

17. Gholami R, Ogun A, Koh E, Lim J (2010) Factors affecting e-payment adoption in Nigeria. Journal of Electronic Commerce in Organizations (JECO) 8(4):51-67

18. Hinkin TR (1995) A review of scale development practices in the study of organizations. J Manag 21(5):967-988

19. Hirschman EC (1979) Differences in consumer purchase behaviour by credit card payment system. Journal of Consumer Research 6(1):58-66

20. Junadi A, Sfenrianto D (2015) A model of factors influencing consumers' intention to use e-payment system in Malasia. Procedia Computer Science 59(1):214-220
21. Kalakota R, Whinston AB (1997) Readings in electronic commerce. Addison-Wesley, Boston

22. Kim C, Tao W, Shin N, Kim KS (2010) An empirical study of customers' perceptions of security and trust in e-payment systems. Electron Commer Res Appl 9(1):84-95

23. Krejcie R, Morgan D (1970) Determining sample size for research activities. Educ Psychol Measur 30:607-610

24. Laudon KC, Traver CG (2001) E-commerce: business, technology, society. Addison-Wesley, Boston

25. Liao W, Handa J (2010) Is the modern economy heading toward a cashless and checkless one? Evidence from the payments system in Canada. IUP Journal of Bank Management 9(4):48-60

26. Nunnally JC, Bernstein IH (1994) Psychometric theory, 3rd edn. New York, McGraw-Hill

27. Omotayo F, Dahunsi O (2015) Factors affecting adoption of point of sale terminals by business organizations in Nigeria. International Journal of Academic Research in Business and Social Sciences 5(10):115-136

28. Oney E, Oksuzoglu Guven G, Hussain Rizvi W (2017) The determinants of electronic payment systems usage from consumers' perspective. Economic research-Ekonomska istraživanja 30(1):394-415

29. Paul A, Friday O (2012) Nigeria's cashless economy: the imperatives. International Journal of Management and Business Studies 2:31-36

30. Prelec D, Loewenstein G (1998) The red and the black: mental accounting of savings and debt. Marketing science 17(1):4-28

31. Romdhane C (2005) Security implications of electronic commerce: a survey of consumers and businesses. Internet Research: Electronic Networking Applications and Policy 9(5):372-382

32. Saunders M, Lewis $P$, Thornhill A (2007) Research methods for business students, 4th edn. Pearson Education Limited, Essex

33. Slozko O, Pelo A (2015) Problems and risks of digital technologies introduction into E-payments. Transformations in Business \& Economics 14(1):225-235

34. Soman D, Gourville JT (2001) Transaction decoupling: how price bundling affects the decision to consume. J Mark Res 38(1):30-44

35. Tee HH, Ong HB (2016) Cashless payment and economic growth. Financial Innovation 2(1):4-12

36. Tijani J (2013) Integrating the unbanked and under-banked Nigeria population into formal financial services through mobile money solution. Journal of Pristine, Zaria 8(1):158

37. Tijani JA, llugbemi AO (2015) Electronic payment channels in the Nigeria banking sector and its impacts on national development. Asian Economic and Financial Review 5(3):521-531

38. Trütsch T (2014) The impact of contactless payment on spending. International Journal of Economic Sciences 3(4):70-98

\section{Publisher's Note}

Springer Nature remains neutral with regard to jurisdictional claims in published maps and institutional affiliations.

\section{Submit your manuscript to a SpringerOpen ${ }^{\oplus}$ journal and benefit from:}

- Convenient online submission

- Rigorous peer review

- Open access: articles freely available online

- High visibility within the field

Retaining the copyright to your article

Submit your next manuscript at springeropen.com 